\title{
"Conchostracan" Records from Western Gondwana Related to Cretaceous Palaeoclimatic Features
}

\author{
Oscar Gallego ${ }^{*}$, Nora Cabaleri², Claudia Armella², Mateo Monferran'1, Victoria Jiménez1, \\ Iracema Zacarías ${ }^{1}$, Diego Silva Nieto ${ }^{3}$ \\ ${ }^{1}$ Centro de Ecología Aplicada del Litoral (CECOAL-CONICET-UNNE), Corrientes, Argentina \\ ${ }^{2}$ Instituto de Geocronología y Geología Isotópica (INGEIS-CONICET-UBA), Ciudad Universitaria, Buenos Aires, Argentina \\ ${ }^{3}$ Servicio Geológico Minero Argentino, Buenos Aires, Argentina \\ Email: *ofgallego@live.com.ar
}

How to cite this paper: Gallego, O., Cabaleri, N., Armella, C., Monferran, M., Jiménez, V., Zacarías, I. and Nieto, D.S. (2019) "Conchostracan" Records from Western Gondwana Related to Cretaceous Palaeoclimatic Features. Open Journal of Geology, 9, 616-618.

https://doi.org/10.4236/ojg.2019.910056

Received: August 16, 2019

Accepted: September 20, 2019

Published: September 23, 2019

Copyright $\odot 2019$ by author(s) and Scientific Research Publishing Inc. This work is licensed under the Creative Commons Attribution International License (CC BY 4.0).

http://creativecommons.org/licenses/by/4.0/

\begin{abstract}
Cretaceous System is widely represented in South America. "Conchostracans" are best represented with 47 early Cretaceous species and only 5 Late Cretaceous ones. Its warm climate with rainfall and marked seasonality allowed the development of the "conchostracan" populations. This information shows that more detailed analysis between climate and "conchostracan" records is needed to reconstruct environments in the Cretaceous times.
\end{abstract}

\section{Keywords}

“Conchostraca”, Cretaceous, Climate, Fossil Record, South America

\section{Introduction}

The Cretaceous System is widely represented in South America, but its geographical outcrop spread is not related to "conchostracan" records, the best represented group among the continental invertebrates [1]. "Conchostracan" first report came from northeast Brazil [2], where the highest diversity record (42 spp. described) was reported, followed by Argentina (6 spp.) and Uruguay (4 spp.) [3] [4]. In Brazil, 37 species came from the early Cretaceous and only 5 to the Late Cretaceous. Ten species from Argentina and Uruguay were found in Lower Cretaceous sequences [3] [4] [5]. The integration of geological and paleontological data will allow inferring the Cretaceous paleoclimate for the southwest Gondwana. 


\section{Cretaceous Climate}

The arid climate, with heavy rainfall, generated favorable seasonal conditions for the development of a diverse "conchostracan" fauna [3] [4] [5]. The diversity of the northeastern Brazil faunas [4] was influenced by the weather. However, it is inferred that, the scarce record in southern South America (e.g. Argentina and Uruguay) is mainly related to collection biases [3] [5]. However, during the Jurassic-Cretaceous periods, marine transgressions and other events (such as magmatism of Serra Geral and Botucatú erg-desert) conditioned the dispersion (marked endemism) and the establishment of continental microfossils (ostracods and charophytes) in Patagonia Argentina and the rest of South America [6]. Subsequently, in [6] analyzed the [4] postulates and applied them to the "conchostracan" faunas found in other sequences, incorporating into this analysis the large South American river drainage networks (Paraná-Uruguay and Orinoco-Amazonas). The climate defined for mid-Cretaceous, maintained favorable characteristics (seasonality) for the development of "conchostracan" faunas. During the late Cretaceous warm weather prevailed with greenhouse periods, globally average temperatures higher than today are recorded. Scarce "conchostracan" records in Brazil, where only 5 species were found, restricts the possibilities of making considerations about the characteristics of the climate and its relationship with the "conchostracan" populations.

\section{Cretaceous Geological Units Bearing "Conchostracan" Faunas}

The main Cretaceous units with "conchostracan" of Argentina are the La Amarga, Lagarcito and Cañadon Calcáreo formations, while of Uruguay only the Tacuarembó and Castellanos formations have been reported, and numerous Brazilian ones [3] [4] [5]. The Cañadón Calcáreo Formation (Upper Jurassic - Lower Cretaceous) with subtropical seasonal dry and warm climatic conditions allowed the establishment of a rich and diverse conchostracan fauna [7]. The Botucatú Formation (paleoerg, Late Jurassic - Early Cretaceous, Brazil) and its equivalent shares 12 species, 3 of them, were referred to another 6 equivalent geological units from the northeast Brazil. The Santana Formation (Lower Cretaceous, Northeast Brazil) with a tropical climate with strong seasonal periods represents favourable conditions to stablish "conchostracan" populations [3]. The Bauru Basin (Upper Cretaceous, Southeast Brasil) was characterized by hot, arid and desert conditions. The scarce "conchostracan" records from the Upper Cretaceous are insufficient to assess to the influence of climate on the "conchostracan" faunas.

\section{Conclusion}

Finally, the still biased and not very diverse record of the South American Cretaceous "conchostracan" faunas prevents us from providing definitive conclusions about the impact of the Cretaceous climate on them. Also, considering that 
South American has a large number of geological units and different environmental conditions and also the paleogeographical context of the southwest Gondwana. However, the climatic characterization for the Cretaceous of South America summarized as a warm climate with rainfall and marked seasonality is characteristics that allowed the development of the "conchostracan" populations. This information shows that we need a more detailed and in-depth analysis of the relationship between the climate and the "conchostracans".

\section{Acknowledgements}

Authors thank Dr. Gang Li for the invitation to IGCP 679 and its first international symposium. Our research was supported by PIP-11220150100117CO (CONICET) and PI-18Q005 (SEGCyT-UNNE). This is a contribution to UNESCO-IUGS IGCP Project 679.

\section{Conflicts of Interest}

The authors declare no conflicts of interest regarding the publication of this paper.

\section{References}

[1] Tasch, P. (1987) Fossil Conchostraca of the Southern Hemisphere and Continental Drift. Paleontology, Biostratigraphy and Dispersal. Geological Society of America, Memoir, 165, 290. https://doi.org/10.1130/MEM165-p1

[2] Jones, R.T. (1897) On some Fossil Entomostraca from South American. Geological Magazine, 4, 259-265. https://doi.org/10.1017/S001675680018611X

[3] Rohn, R. and Cavalheiro, M.C.T. (1996) Conchostráceos Cretácicos da Bacia de Tucano (Bahia) e avaliação do potencial cronoestratigráfico destes crustáceos no Mesozóico do Brasil. 4º Simpósio sobre o Cretáceo do Brasil, Boletim, 157-167.

[4] Musacchio, E.A. (2001) Relaciones Paleobiogeográficas de los Ostrácodos no Marinos del Jurásico y el Cretácico de Patagonia. Acta Geologica Leopoldensia, 24, 293-310.

[5] Gallego, O.F. (2001) Conchostracofauna Sudamericana del Paleozoico y Mesozoico: estado actual del conocimiento. Parte I: Argentina y Chile and Parte II: Sur de Brasil y Uruguay. Acta Geológica Leopoldensia, 24, 311-337.

[6] Gallego, O.F. and Rinaldi, S. (2004) Grandes Sistemas Fluviales y Paleovientos Alisios. Posibles Vías de Dispersión para las Conchostracofaunas jurásico-cretácicas sudamericanas. Reunión de Comunicaciones Científicas y Tecnológicas, Resúmenes B-050.

[7] Volkheimer, W., Gallego, O., Cabaleri, N.G., Armella, C., Narváez, P., Silva Nieto, D. and Paez, M. (2009) Stratigraphy, Palynology, and Conchostracans of a Lower Cretaceous Sequence at the Cañadón Calcáreo Locality, Extra-Andean Central Patagonia: Age and Palaeoenvironmental Significance. Cretaceous Research, 30, 270-282. https://doi.org/10.1016/j.cretres.2008.07.010 